\title{
SEASONAL DYNAMICS OF PRODUCTS OF LIPID PEROXIDATION IN LIVER OF BANK VOLE (Myodes glareolus) UNDER CONDITIONS OF ENVIRONMENTAL POLLUTION BY HEAVY METALS
}

\author{
S. V. ZADYRA, D. V. LUKASHOV \\ Taras Shevchenko Kyiv National University, \\ Educational and Scientific Centre «Institute of Biology», Ukraine; \\ e-mail: luminary_SV@ukr.net
}

\begin{abstract}
The presented research involves the integral assessment of biochemistry indexes of natural populations of voles under conditions of environmental pollution by heavy metals. The raised content of mobile forms of $P b$, $\mathrm{Cd}, \mathrm{Cr}, \mathrm{Ni}$ and $\mathrm{Co}$ in soils was revealed for a distance of $500 \mathrm{~m}$ to the south-west of Tripillya Thermal Power Plant (TPP) (Kyiv region, Ukraine). It considerably (up to 3-5 times) exceeds the levels in the territory of Kaniv Nature Reserve (Cherkassy region, Ukraine). The territory of National Nature Park «Holosiivsky» (Kyiv, Ukraine) is characterized by rather increased content of active form of investigated heavy metals, especially $P b$. The increase of the concentration of diene conjugates (up to 7-10 times) and thiobarbituric acid (TBA) active compounds (up to 2-3 times) in the liver of bank vole (Myodes glareolus) polluted by heavy metals has been found. The insignificant increase of the content of Schiff bases in liver homogenate of voles in the region of impact of the Tripillya TPP (2 times in spring and summer, 3 times - in autumn) was detected. Seasonal dynamics of the maintenance of lipid peroxidation products has been revealed. The registered changes of biochemical indicators evidence for availability of biochemical stress in the bank vole organism in the region of influence of the Tripillya TPP.
\end{abstract}

Key words: heavy metals, bank vole (Myodes glareolus), lipid peroxidation, environmental pollution.

$\mathrm{M}$ an-caused chemical pollution of ecosystems is an urgent problem at present. Concentration of industrial plants in big cities, near towns and villages makes it difficult to monitor their negative impact on the environment [1-3]. Intensive production results in releasing great amounts of heavy metals that extend in the atmosphere and are involved in circulation of elements. Their ranges exceed many times the natural amount of metals at different levels of the biosphere. Lead, mercury, cadmium, copper and zinc are widely distributed in the biosphere among man-caused metals. They are mainly released under the burning of mineral fuel. Ashes, nitric oxides, sulfur anhydride, vanadium pentoxide, carbon oxide and benzapilene are main products formed under the burning of coal. Concentration of heavy metals in coal ashes is as follows: $\mathrm{Cu}$ is $35 \mathrm{mg} / \mathrm{kg}, \mathrm{Zn}-85 \mathrm{mg} / \mathrm{kg}, \mathrm{Pb}-20 \mathrm{mg} / \mathrm{kg}$, $\mathrm{Cr}-123 \mathrm{mg} / \mathrm{kg}, \mathrm{Ni}-62 \mathrm{mg} / \mathrm{kg}, \mathrm{Cd}-4 \mathrm{mg} / \mathrm{kg}$, $\mathrm{Co}-114 \mathrm{mg} / \mathrm{kg}$ [4]. Anthropogenic emission is so strong that under the burning of bituminous coal the number of metals dispersed in the atmosphere is much more than that extracted by people from deposits [5]. The areas of pollutions in snow cover nearby big thermoelectric power plants are formed within the range of $10-20 \mathrm{~km}$. Winds contribute to formation of the dispersion halos [4]. The Kyiv Region is one of the most contaminated in Ukraine. Four hundred forty three (443) industrial plants are the sources of air pollution in the Kyiv Region. Among the region areas the biggest polluters are located in the Obukhiv district; the amount of its industrial discharges is about 83000 tons a year. The strongest polluter is Tripillya TPP - over 21000 tons a year. It forms $84 \%$ of all discharges in the atmosphere from industrial plants in the Kyiv Region [6].

It is topical to clarify specific mechanisms of influence of a large plant (e.g., thermoelectric power station) located in densely populated region on the environment. Small mammals are the most convenient objects for such investigations as long as they are animals that inhabit transformed ecosystems directly near with human. Via short life cycle forest rodents have time to reflect the impact of the environment on their organism [5]. It is known that the activation of lipid peroxidation processes in cell membranes is the reflection of toxic heavy metals' impact [1]. The liver is the most important organ of detoxication. The presented research involves the integral assessment of biochemistry in- 
dexes of natural populations of voles in the district of the Tripillya TPP influence. The goal of the research is to define the basic biochemical indicators in the bank vole organism under conditions of environmental pollution by heavy metals.

\section{Materials and Methods}

Researches were conducted on natural population of the bank vole (Myodes glareolus Schreber, 1780), in the territories with different level of anthropogenic pollution. This species habitat is closely concerned with soil bedding. Therefore M. glareolus may be used as a biomonitor of mancaused pollution of the environment.

Three areas with different level of anthropogenic loading were chosen for comparative analysis. The territory of the Kaniv Nature Reserve (Cherkassy region, Ukraine) that is the nature reserve with the highest protection status was chosen as the least disturbed landscape. The territory of the National Nature Park «Holosiivsky» (Kyiv, Ukraine) is similar, as to phytocenosis structure (hornbeam forest), to the Kaniv Nature Reserve. It feels direct and indirect impact of human activity starting with disturbing factor and ending with air pollution by discharges. The zone of impact of the Tripillya TPP (Obukhiv district, Kyiv region) with small hornbeam plantation adjoins the south-west edge of the industrial area of thermoelectric power plant (about 500 meters). The industrial area rather works on bituminous coal thus getting under the torch of dispersion [4].

The results of control catches of M. glareolus in the chosen areas were used in the research. The control catches were conducted according to generally accepted methods in spring, in summer and in autumn 2012 [7]. General amount of analyzed animals is 230 specimens. Among them 111 specimens were from the Kaniv Nature Reserve, 61 specimens - from the National Nature Park «Holosiivsky», 58 specimens - from the Tripillya TPP. The material was collected on registered spots with the area of $3025 \mathrm{~m}^{2}$ which are chosen for assessment of density of individuals' distribution.

The content of heavy metals in the upper soil stratum of $5 \mathrm{~cm}$ and in the liver were determined by flame atomic-absorption spectrophotometer C115-M1 (SELMICHROM, Ukraine) with heavy hydrogen corrector of the background and computer complex CAS-120. The content of acid-soluble metals and their exchange fraction in soil were analyzed by extraction with acetate-ammonium buffer ( $\mathrm{pH} \mathrm{4.8;} \mathrm{molarity} \mathrm{-} 1.1 \mathrm{~mol} / \mathrm{L})$ according to standard methods [8]. The content of metals in the samples was estimated in $\mathrm{mg}$ per $\mathrm{kg}$ of masses of air dried recoveries.
The objects (M. glareolus) were anesthetized using ether and chloroform. Anesthetic agents were introduced into the organism by inhalation in a confined space. According to the rules of humane treatment of animals, bank voles were subjected to euthanasia by destruction of the spinal cord. The liver was removed at a room temperature.

The samples for determining the content of lipid peroxidation products were obtained by preparing $10 \%$ liver homogenate in terms of $1 \mathrm{mg}$ of liver tissue per $10 \mathrm{ml}$ of $0.9 \%$ solution of sodium chloride (physiological solution). Firstly, a tissue sample was washed in $10 \%$ sodium chloride solution. After that, the sample was refrigerated in liquid nitrogen. Before the experiment the sample was carefully crumbled up in chilled porcelain mortar.

A list of reagents, used in determination of lipid peroxidation products: heptane (Alfarus, Ukraine); isopropanol (Sistema Optimum ChP, Ukraine); $0.9 \%$ solution of sodium chloride (OJSC «Biosintez», Russia); ethanol (Bio-Product LTD, Ukraine); $0.025 \mathrm{M}$ tris- $\mathrm{HCl}$ buffer solution ( $\mathrm{pH}$ 7.4), with $0.175 \mathrm{M}$ solution of potassium chloride (Shanghai Hanwish Industrial CO., LTD, China); $20 \%$ trichloroacetic acid solution (Farmak, Ukraine); $0.8 \%$ water solution of 2-thiobarbituric acid (SFERA SIM, Ukraine).

The level of lipid peroxidation products was estimated by the content of primary (diene conjugates), secondary (malonic dialdehyde or TBAactive compounds) and terminal (Schiff bases) metabolites. During the lipid peroxidation on the stage of formation of free radicals in molecules of polyunsaturated higher fatty acids the system of conjugated binary links is formed. Conjugated dienes are formed as a result. It is accompanied by the appearance of a new maximum in the absorption spectrum on the wave of $233 \mathrm{~nm}$; $\varepsilon=2,2 \cdot 10^{5} \mathrm{~cm}^{-1} \cdot \mathrm{M}^{-1}[9]$.

Since conjugated dienes differ by intensive absorption in ultraviolet (UV) spectra, spectrophotometric methods were used for identification of diene conjugates. Identification of contents of TBA-active compounds was conducted by spectrophotometric methods (Shimadzu, UV mini-1240 model, Japan). TBA-active compounds were detected in reaction with 2-thiobarbituric acid [9]. Calculation of TBA-active compounds concentration was conducted taking into account the value of coefficient of molecular extinction of malonic dialdehyde on $532 \mathrm{~nm} ; \varepsilon=1.56 \cdot 10^{5} \mathrm{~cm}^{-1} \cdot \mathrm{M}^{-1}$. The content of diene conjugates and TBA-active compounds was calculated in nmol per $\mathrm{mg}$ of sample. Content of the Schiff base was calculated in conventional units per $1 \mathrm{ml}$ of sample that was detected by spectrofluorometric method (the length of exci- 
tation wave is $360 \mathrm{~nm}$; the length of emission wave is $420 \mathrm{~nm}$; Shimadzu, RF-1501 model, Japan) [9].

Because of misfit of normal distribution of some sampling variative ranks of investigated indexes the average size of lipid peroxidation products and content of metals were presented as median (Me). Standard deviation of the median (SDMe) was used as the variation index. Man-Whitney's U-Index was used for comparative characteristic of sampling parameters. For all statistical analysis the STATISTICA 6.0 statistical package was used.

\section{Results and Discussion}

Soil is a specific component of the biosphere. It not only accumulates contaminants but also serves as a natural buffer that controls the transfer processes of chemical elements and compounds from dry lands to the atmosphere, hydrosphere and living organisms. The lifetime of contaminants in soil is much longer than in other components of the biosphere. Therefore contamination of soil, particularly by heavy metals, is practically perpetual. Compounds of heavy metals falling on the earth surface with atmospheric precipitates are accumulated in soil thickness, especially in upper humus levels and are slowly removed under leaching, erosion, deflation and extraction by plants. The period of semi-extraction for $\mathrm{Pb}$ from soil is a few thousand years, for $\mathrm{Cd}$ it is up to 1.1 thousand years, for $\mathrm{Zn}-$ up to 0.5 thousand years [1]. It may be supposed that under permanent source of air contamination a gradual increase of heavy metals' content in the upper layer of soil will occur. It may serve as index of contamination of the investigated territory [4]. Research of content of heavy metals $(\mathrm{Pb}, \mathrm{Cd}, \mathrm{Cr}, \mathrm{Ni}, \mathrm{Co})$ in soil samples displays the significant differences of selected regions under exchange fraction (Table).
Differences of soil in researched regions as to the content of acid-soluble fraction of heavy metals were found statistically insignificant and corresponded to the value of regional clark typical of the forest-steppe zone of Ukraine [10]. The excess of normative indexes of boundary permissible concentrations for arable soil has not been found. But the analysis of heavy metals exchange fraction showed that its content in the Kaniv $\mathrm{Na}$ ture Reserve is the least. Soil at the National Nature Park «Holosiivsky» was characterized by the increased content of $\mathrm{Pb}$. In the region of impact of the Tripillya TPP the content of active forms of all investigated heavy metals in soil are greatly (up to 3-5 times, $P<0$. 05) exceeding the levels that is typical of the nature reserve territory. Thus one can argue that the consistent increase of part of biological available fraction of the investigated heavy metals in soil was observed: the Kaniv Nature Reserve < the National Nature Park «Holosiivsky» < region of impact of the Tripillya TPP. The increase of the content of exchange fraction of heavy metals in soils of the last two regions was probably conditioned by the processes of atmospheric contaminants transportation and contaminants fall-out (the presence of a big city nearby the National Nature Park «Holosiivsky» and powerful Tripillya TPP). It will be shown that in every case the exceeding of normative indexes of boundary permissible concentrations of heavy metals for arable lands was not determined. It may be understood by the existing environmental standards as a satisfactory ecological situation in all investigated territories.

The same results of soils pollution by heavy metals in the territories adjacent to the Tripillya TPP were obtained by other researchers [4]. The estimation shows that thanks to irregular disper-

Content of exchange fraction of heavy metals in samples of the upper soil level in investigated territories

\begin{tabular}{|c|c|c|c|c|c|c|c|c|c|c|}
\hline \multirow{3}{*}{$\begin{array}{c}\text { Territory } \\
\text { of investigation }\end{array}$} & \multicolumn{10}{|c|}{ Content of metals, $\mathrm{mg} / \mathrm{kg}$} \\
\hline & \multicolumn{2}{|c|}{$\mathrm{Pb}$} & \multicolumn{2}{|c|}{$\mathrm{Cd}$} & \multicolumn{2}{|c|}{$\mathrm{Cr}$} & \multicolumn{2}{|c|}{$\mathrm{Ni}$} & \multicolumn{2}{|c|}{$\mathrm{Co}$} \\
\hline & $\mathrm{Me}$ & $\mathrm{SD}_{\mathrm{Me}}$ & $\mathrm{Me}$ & $\mathrm{SD}_{\mathrm{Me}}$ & $\mathrm{Me}$ & $\mathrm{SD}_{\mathrm{Me}}$ & $\mathrm{Me}$ & $\mathrm{SD}_{\mathrm{Me}}$ & $\mathrm{Me}$ & $\mathrm{SD}_{\mathrm{M}}$ \\
\hline $\begin{array}{l}\text { Kaniv Nature Reserv } \\
\text { (Cherkassy region, } \\
\text { Ukraine) }\end{array}$ & $<0.19$ & - & $<0.002$ & - & 0.07 & 0.03 & 0.08 & 0.07 & 0.05 & 0.04 \\
\hline $\begin{array}{l}\text { National Nature Parl } \\
\text { «Holosiivsky» } \\
\text { (Kyiv, Ukraine) }\end{array}$ & 0.27 & 0.09 & $<0,003$ & - & 0.12 & 0.02 & 0.10 & 0.06 & 0.11 & 0.06 \\
\hline $\begin{array}{l}\text { Region of impact of } \\
\text { Tripillya TPP (Kyiv } \\
\text { region, Ukraine) }\end{array}$ & 0.34 & 0.05 & 0.03 & 0.00 & 0.17 & 0.14 & 0.30 & 0.05 & 0.25 & 0.01 \\
\hline
\end{tabular}


sion of smoke fumes discharges of the station 26.336.0 ton per $\mathrm{km}^{2}$ of man-caused dust is falling out in south-east direction annually. That is why the soils are enriched by compounds of $\mathrm{Cd}, \mathrm{Pb}, \mathrm{Cr}$. Thus it may be stated that the region around the Tripillya TPP, as to the content of heavy metals $(\mathrm{Pb}, \mathrm{Cd}, \mathrm{Cr}, \mathrm{Ni}, \mathrm{Co})$, is a man-caused contaminated territory. The territory of the National Nature Park «Holosiivsky» is characterized by rather high content of active form of investigated heavy metals, especially $\mathrm{Pb}$.

In the National Nature Park «Holosiivsky» a significant increase of bank vole's population density is observed during different seasons of a year: in spring -20 individuals per hectare, in summer - 20 individuals per hectare, in autumn 11 individuals per hectare. In the Kaniv Nature Reserve and in the region of impact of the Tripillya TPP the highest density was observed in summer (48 individuals per hectare and 20 individuals per hectare, accordingly). The value of density was minimal in spring and in autumn: 22 individuals per hectare and 21 individuals per hectare, accordingly, in the Kaniv Nature Reserve; 14 individuals per hectare and 14 individuals per hectare, accordingly, in the territory next to Tripillya TPP. Thus maximum density in the most contaminated territory next to powerful TPP was observed in summer, while minimum density was observed in spring and in autumn.

While analyzing the content of heavy metals in the bank vole's liver in the investigated territories, the insignificant increase of $\mathrm{Cu}, \mathrm{Zn}, \mathrm{Cr}, \mathrm{Mn}$ content was detected in the region of impact of the Tripillya TPP. Thus the content of $\mathrm{Cu}$ and $\mathrm{Cr}$ in the liver was by $29 \%$ higher in the contaminated territory than in reserved territory, the content of $\mathrm{Zn}$ and $\mathrm{Mn}$ - by $34 \%$. So the heavy metals are accumulated in the bank vole's liver from population in the region of the Tripillya TPP impact. It probably may cause physiological disturbance in organism.

Biochemical changes in organism are the most accurate indexes of direct impact of heavy metals. The products of lipid peroxidation in homogenate of the bank vole's liver from natural populations were analyzed for the changes of biochemical indexes. An analysis of lipid peroxidation content products in voles' organism from investigated territories showed considerable differences $(P<0.05)$.

As a result of investigation of diene conjugates' content in the liver homogenate the increasing of these products in bank vole in contaminated territory during different seasons 2012 was determined (Fig., A). In spring it was up to 9 times higher in the region of impact of the Tripillya TPP as against the nature reserve territory, in summer it was up to 10 times higher, accordingly, and in autumn - up to 7 times.

It should be mentioned that the maximum concentration of diene conjugates in the National Nature Park «Holosiivsky» was detected in autumn, while the content of primary metabolites had descended in summer. As it is well known, diene conjugates concern to toxic metabolites that provide damage impact on enzymes, ferments and nucleic acids [11]. Therefore it may be assumed that the content of diene conjugates depends on metabolism intensity in the organism. In our investigations the increasing quantity of toxic product in bank vole individuals was detected during the year in the territory next to the Tripillya TPP.

The study of content of TBA-active compounds showed the increasing of its concentration near the territory of the Tripillya TPP during 2012 in comparison with reserved territory: a 2-fold increase had been recorded in spring, 3-fold - in summer and in autumn (Fig., B). Such increasing of TBA-active compounds possibly was closely concerned with entry of heavy metals with food. It probably leads to affection of the liver cell membranes.

An important role in synthesis of prostaglandins, progesterone and other steroids belongs to TBA-active compounds [12]. The negative role of TBA-active compounds consists in cross-linking of lipid molecules and deterioration of penetration of membranes. As a result the membrane becomes less labile. The processes concerned with the change of membrane surface (e.g. phagocytosis, pinocytosis, cell migration) were broken [11].

The Schiff base formation is a final product of lipid peroxidation as a result of interaction of secondary products of lipid peroxidation with proteins and phospholipids which contains amides. The analysis of the Schiff base content is insignificant but statistically considerable exceeding of its concentration in the liver of voles was detected in the region of impact of the Tripillya TPP (Fig., $C)$. The clear gradual decrease of its content could be noted during the vegetative season from 0.0032 conventional units/mg in spring to 0.0031 conventional units/mg in autumn. In reserved territories the content of the Schiff base in the liver of voles was practically constant during the vegetative season. Such difference in dynamics of the Schiff base in the territories with different level contamination of top-soil may be explained by the compliance of accumulation of that product to more deep changes of oxide homeostasis [11]. A considerable increase of that index is mostly the consequence of serious tissue affection. 


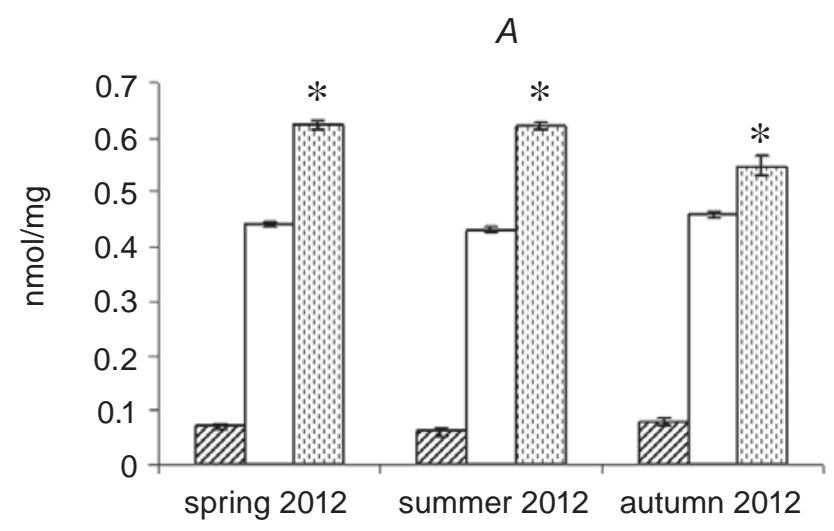

$B$

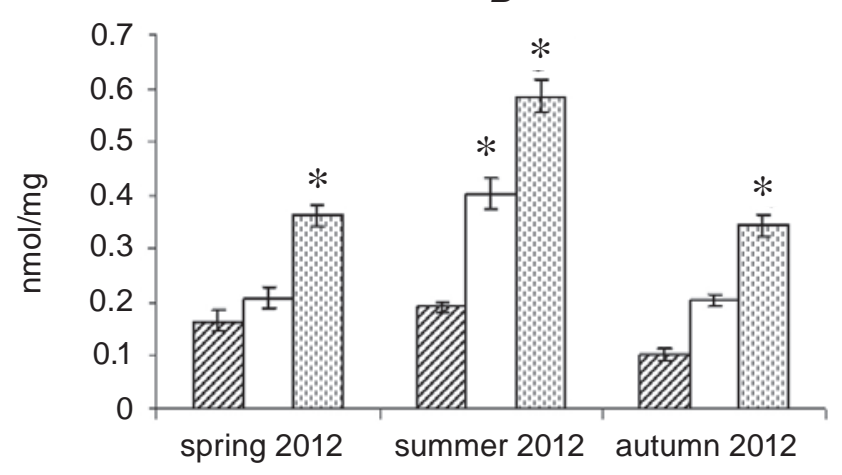

$C$

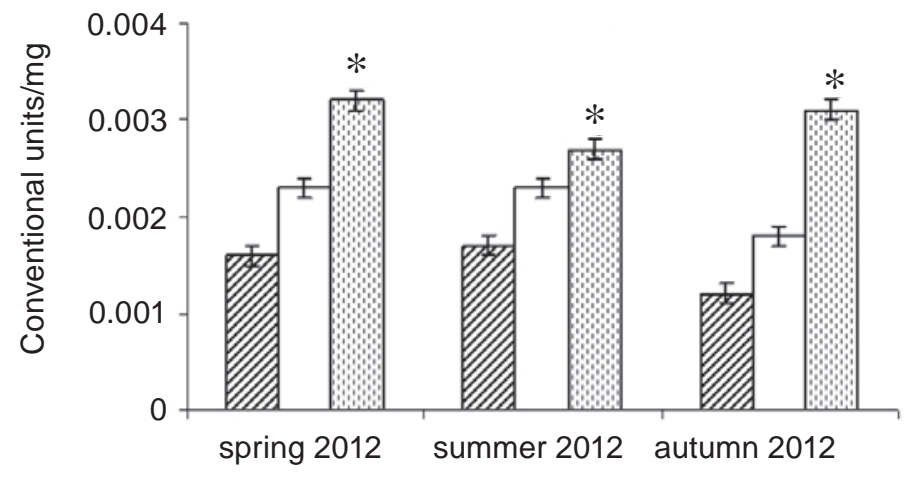

■aniv Nature Reserve

National Nature Park «Holosiivsky»

四 Region of impact of Tripillya TPP

Content of lipid peroxidation products in liver homogenate of natural populations of voles from investigated territories: $A$ - content of diene conjugates (in spring $n=40$; in summer $n=14$; in autumn $n=12$ ); $B-$ content of TBA-active (in spring $n=40$; in summer $n=14$; in autumn $n=12$ ); $C$ - content of Schiff base (in spring $n=40$; in summer $n=14$; in autumn $n=12)$. Note: ${ }^{*}-$ statistically significant differences $(P<0.05)$

It is well known that the entrance of toxic substances to organism of warm-blooded animals stimulates the generation of active forms of oxygen [5]. Under disturbance or overcharge of inactivation molecular mechanisms of these radicals the intensification of processes of free-radical oxidation and accumulation of products of lipid peroxidation are possible.
Inhibition of these processes is carried out at the expense of endogenous antioxidants - vitamin A, E and others. Accumulation of lipid peroxidation products under conditions of toxic pollution is concerned with exhaustion of resources of endogenous protectors [1]. The disturbance of cell membranes' structure and ferment system of the 
organism metabolism that is the appearance of intoxication characteristics becomes a consequence.

The results of this research show that the content of heavy metals in soil and in the liver of bank vole population is the highest in the region of impact of the Tripillya TPP (most contaminated among researched territories) as against the Kaniv Nature Reserve that is the background territory. Considerable accumulation of lipid peroxidation products in the liver cells of voles from the Tripillya TPP area as against the nature reserve territory in spring (diene conjugates - 9 times; MDD - 2 times), in summer and in autumn (diene conjugates - 10 times and 7 times; TBA-active compounds - 3 times, accordingly) was stated. The insignificant increase of the Schiff base content in the liver cells of voles in the region of impact of the Tripillya TPP (2 times in spring and in summer, 3 times in autumn) was detected.

Thus the exceeding of the levels of maximum permissible concentrations for soil was not detected in the investigated territories but biochemical features of disturbance in the organism of bank vole from natural populations were observed. Thus the conformity of chemical composition of soils to the maximum permissible concentrations does not correspond to safe condition of the animal organism which existence is connected with the paedosphere. Therefore it may be concluded that absolute content of heavy metals in soil is not a marker of ecological conditions of the environment. The registered changes of biochemical parameters can evidence for availability of biochemical stress in the bank vole organism in the region of influence of the Tripillya TPP.

\section{СЕЗОННА ДИНАМІКА ПРОДУКТІВ ПЕРОКСИДНОГО ОКИСЛЕННЯ ЛІПІДІВ У ПЕЧІНЦІ РУДОЇ НОРИЦІ (Myodes glareolus) В УМОВАХ ЗАБРУДНЕННЯ ДОВКІЛЛЯ ВАЖКИМИ МЕТАЛАМИ}

\section{С. В. Задира, Д. В. Лукашов}

\author{
Київський національний університет \\ імені Тараса Шевченка, \\ ННЦ «нститут біології, Україна; \\ e-mail: luminary_SV@ukr.net
}

Робота присвячена інтегральній оцінці біохімічних показників природних популяцій нориць в умовах забруднення довкілля важкими металами. На відстані 500 м на південний схід від Трипільської теплової електростанції (ТЕС, Київська обл., Україна) виявлено підвищений вміст у грунтах рухомих форм
$\mathrm{Pb}, \mathrm{Cd}, \mathrm{Cr}$, Ni та Co, що значно (у 3-5 разів) перевищує рівні, характерні для Канівського природного заповідника (Черкаська обл., Україна). Територія Національного природного парку «Голосіївський» (Київ) характеризується дещо підвищеним вмістом рухливих форм досліджених важких металів, особливо $\mathrm{Pb}$. В умовах забруднення важкими металами грунтового покриву встановлено збільшення концентрації дієнових кон'югатів у 7-10 разів, ТБК-активних сполук - у 2-3 рази у печінці особин рудої нориці. Встановлено незначне підвищення вмісту шиффових основ у гомогенаті печінки нориць в районі впливу Трипільської ТЕС (в 2 рази навесні та влітку, восени - в 3 рази). Виявлено сезонну динаміку вмісту продуктів пероксидного окислення ліпідів. Висловлюється припущення, що зареєстровані зміни свідчать про наявність біохімічного стресу у рудої нориці в районі впливу теплоелектростанції.

Кл юч ов і слова: важкі метали, руда нориця (Myodes glareolus), пероксидне окислення ліпідів, забруднення довкілля.

\section{СЕЗОННАЯ ДИНАМИКА ПРОДУКТОВ ПЕРОКСИДНОГО ОКИСЛЕНИЯ ЛИПИДОВ В ПЕЧЕНИ РЫЖЕЙ ПОЛЕВКИ (Myodes glareolus) В УСЛОВИЯХ ЗАГРЯЗНЕНИЯ ОКРУЖАЮЩЕЙ СРЕДЫ ТЯЖЕЛЫМИ МЕТАЛЛАМИ}

\section{С. В. Задыра, Д. В. Лукашев}

\author{
Киевский национальный университет \\ имени Тараса Шевченко, \\ УНЦ «Институт биологии», Украина; \\ e-mail: luminary_SV@ukr.net
}

Работа посвящена интегральной оценке биохимических показателей природных популяций полевок в условиях загрязнения окружающей среды тяжелыми металлами. На расстоянии 500 м к юго-востоку от Трипольской тепловой электростанции (ТЭС, Киевская обл., Украина) обнаружено повышенное содержание в почвах подвижных форм $\mathrm{Pb}, \mathrm{Cd}, \mathrm{Cr}, \mathrm{Ni}$ и Со, что значительно (в 3-5 раз) превышает уровни, характерные для Каневского природного заповедника (Черкасская обл., Украина). Территория Национального природного парка «Голосеевский» (Киев) характеризируется повышенным содержанием подвижных форм исследуемых тяжелых металлов, особенно $\mathrm{Pb}$. В загрязненной тяжелыми металлами почве выявлено увеличение концентрации диеновых 
конъюгатов в 7-10 раз и ТБК-активных продуктов - в 2-4 раза в печени рыжей полевки. Показано незначительное повышение шиффовых оснований в гомогенате печени полевок в районе влияния Трипольской ТЭС (в 2 раза весной и летом, осенью - в 3 раза). Установлена сезонная динамика содержания продуктов пероксидного окисления липидов. Высказывается предположение, что зарегистрированные изменения свидетельствуют о наличии биохимического стресса у рыжей полевки в районе влияния теплоэлектростанции.

К л юч в ы е с лова: тяжелые металлы, рыжая полевка (Myodes glareolus), пероксидное окисление липидов, загрязнение окружающей среды.

1. Курляндский Б. А., Филов В. А. Общая токсикология. - М.: Медицина, 2002. $606 \mathrm{c}$.

2. Cristald M., Mascarzon D. // Sci. Total Envir. 1990. - 99. - P. 61.

3. Saldiva P. H. N., Bohm G. M. // Ecosystem Health. - 2002. - 4, N 4. - P. 230-235.

4. Красовський Г. Я., Трофимчук О. М., Крета Д. Л. та ін. // Екологія і ресурси. 2005. - 12. - C. 37-55.
5. Безель В. С. Экологическая токсикология: популяционный и биоценотический аспекты. - Екатеринбург: Гощицкий, 2006. -280 с.

6. Безкоровайний O. I. Екологічний паспорт Київської області. - К.: Мін-во екол. та природ. ресурс. України, 2011. - 93 с.

7. Гашев С. Н., Сазонова Н. А., Селюков А. Г. идр. Методика комплексной оценки состояния сообществ и популяций доминирующих видов или видов-индикаторов мелких млекопитающих, амфибий и рыб. Тюмень: ТюмГУ, 2005. - 94 с.

8. Минеев В. Г., Сычев В. Г., Амельянчик О. А. и $\partial p$. Практикум по агрохимии. - М.: Изд-во МГУ, 2001. - 689 с.

9. Орехович B. H. Современные методы в биохимии. - М.: Медицина, 1977. - 391 с.

10. Фатєєв А. I., Пащенко Я. В. Фоновий вміст мікроелементів у грунтах України. Харків: ННЦ, 2003. - 118 с.

11. Christina S. Sander, Hong Chang // Allerg. 2005. - 60. - P. 1014-1020.

12. Briganti S., Picardo M. // J. Eur. Acad. Dermatol. Venerol. - 2003. - 17. - P. 663-669.

Received 29.03.2013 